\title{
Organic Fertilization, Cover Crops and Plastic Mulching Effects on Soil Temperture and Moisture, Vegetative Growth, Yield and Fruit Quality of "Anna"Apple Trees
}

\author{
Aly, M. A. ${ }^{1}$, Nagwa, A. Abd El-Megeed ${ }^{2}$ and Afaf, M. A. Yousif ${ }^{2}$
}

\begin{abstract}
Apple orchard cv. Anna/MM106 rootstock planted in 2003 at $4 \times 3 \mathrm{~m}$ at Al- Nubaria, Behira governorate, were treated during 2009 and 2010 seasons in the inter-row spaces by: 1) check - plots, CP (Control); 2) black polyethylene film, BPF (from the tree trunk to the tree canopy, $0.12 \mathrm{~mm}$ thick applied from February to October each season); 3) white polyethylene film, WPF (from the tree trunk to the tree canopy, $0.12 \mathrm{~mm}$ thick applied from February to October each season); 4) mulching with Alfalfa straw, MAS; 5) mulching with Rice straw, MRS and 6) compost of organic matter, COM (15m3/Fed.) applied once at December. Trees were planted in a sandy loam with a $\mathrm{pH}$ of 7.6 and irrigation was drip system. Results indicated that, all plastic mulch coverings treatments (BPF and WPF) and applied compost of organic matter (COM) showed an increment in soil temperature and soil moisture content in both seasons as compared with control treatment. Moreover, plastic films around the trees gave the highest increment in shoot length, number of leaves/shoot and leaf area followed by mulching with alfalfa or rice coverings soil treatments as compared with check plot treatment, while the compost organic matter treatment gave the lowest value in both experimental seasons. Also, all mulching treatments with plastic films, covering crops, as well as, compost organic matter caused an increased fruit weight $(\mathrm{g})$, tree yield $(\mathrm{Kg})$, fruit length, fruit diameter and fruit firmness as compared with check plot treatment in both seasons. Fruit color percentages had greater light intensity at all polyethylene films applications than light reflected from the other covering crops, compost organic matter and untreated trees. The same trend was found for anthocyanin contents in fruits at both seasons. Concerning the TSS \% and acidity \%, results showed that mulching treatments either with polyethylene or cover crops decreased the two parameters comparing with control treatment in both seasons, while the reverse was true for starch and total sugar contents. Moreover, the applied treatments increased significantly leaf and fruit $\mathrm{N}, \mathrm{P}, \mathrm{K}$, $\mathrm{Fe}, \mathrm{Zn}$ and Mn contents as compared with the control treatment in both seasons.
\end{abstract}

\section{INTRODUCTION}

Mulching systems, including cover crops and living mulches, offer the potential for adequate weed control along with benefits for water conservation and soil fertility. Mulching with organic materials is highly beneficial in many orchard crops. It precludes weed growth, lowers soil temperature in the root zone, conserves water, reduces soil erosion and increases microbial activity within the mulch and soil, increases humus, organic matter, water percolation and soil nutrition. Mulches may increase disease pressure by maintaining increased humidity within a tree microclimate, e.g., mulches increase the incidence and severity of root rot of citrus trees (Granatstein, 2002).

Cover crops may have substantial effects on several components of agro- ecosystems. They are used for several purposes such as to enhance the natural control of arthropod pests, to suppress weeds and as an alternative to nitrogen fertilizers (Hamm el al., 2002 and Mika et al., 2007). The cultivation of the surface soil to keep it free of vegetation and wet to capture solar heat, which is released at night, warming the orchard. This practice induces organic matter breakdown and negatively affects soil structure, aggregate stability and favors soil compaction among other physical and chemical soil properties (Cambardella and Elliott, 1993 and Balesdent et al., 2000).

Research on cover crops, to a large extent, has been confined to their effects on succeeding cereal crops (Hanna et al., 1995 and Sainju and Singh, 1997).The reduction of soil temperature has other aspects that need consideration. Growth in the spring could be delayed, and transient micronutrient deficiencies do occur under cold soil temperatures. Mulches inhibit the release (as well as the absorption) of radiant energy, which could be important on cold nights. Thus, mulches should be applied to cold- sensitive crops only after the danger of late frost has passed.

Organic fruit production (OFP) has been steadily increasing in recent years due to the excellent returns for growers. The most important fruit crops are pears and apples. Growers considering switching from conventional to organic production can face challenges with soil fertility management one of the most relevant (Granatstein, 2002).Organic and integrated apple management systems offer alternative practices that address environmental concerns (National Research Council, 1989). Organic management practices exclude chemical pesticide and fertilizer inputs and use naturally

\footnotetext{
${ }^{1}$ Fac. of Agric., Saba Bacha, Plant Prod. Dep. Alex. Univ.

${ }^{2}$ Hort. Res. Inst., Agric. Res. Center, Giza, Egypt

Received December20, 2010, Accepted December30, 2010.
} 
derived products as defined by organic certification programs. Although studies have found that alternative management practices may improve soil quality as compared to conventional management practices (Reganold et al., 1987, 2001, and Swezey et al., 1998).

Our studies were conducted to determine the effects of various mulches, organic fertilization and cover crops on soil temperature and moisture, vegetative growth, yield components, leaf and fruit mineral contents, tree growth of drip-fertigated "Anna" apple trees.

\section{MATERIALS AND METHODS}

Studies were conducted during 2009 and 2010 seasons in a private farm on 6 years old 'Anna' apple cultivar on $\mathrm{MM} / 106$ as a rootstock grown at AlNubaria, Behira governorate. The trees in this experiment were planted at $3 \times 4 \mathrm{~m}$ spacing. Specific details concerning the soil analysis and plastic cover sheets are presented in Tables (1 and 2). Soil samples were, randomly, taken from two depths $(0-30 \mathrm{~cm}$ and $30-60 \mathrm{~cm}$ ) prior to initiating of the experiment and analyzed for physical and chemical properties. A randomized complete block experimental design was used in this trial using five trees for each treatment. The orchard was fertilized with organic manure at a rate of $10 \mathrm{~m}^{3} /$ feddan in December year by year. Ammonium sulphate was added at the rate of $2.5 \mathrm{Kg} /$ tree in three equal doses; the first in early March before blooming, the second in May after fruit set and the third in June. Superphosphate was used at the rate of $1.5 \mathrm{Kg}$ /tree in February. Potassium sulphate was also added at the rate of $2.0 \mathrm{Kg} /$ tree in two equal doses; March and May. Thirty 'Anna' apple trees nearly uniform as possible in growth vigor and productivity were chosen for this study. The trees were subjected to fertigation system used in the practical field. Trees were trained to the central leader system. Other cultural practices were applied in a manner consistent with those of commercial 'Anna' apple orchards.

Table 1. The physical and chemical properties of the sandy soil of the experimental site before starting the experiment

\begin{tabular}{|c|c|c|c|c|c|c|c|c|c|c|}
\hline \multirow[t]{2}{*}{$\begin{array}{l}\text { Soil Depth } \\
\text { (cm) }\end{array}$} & \multirow[t]{2}{*}{ Texture } & \multirow[t]{2}{*}{ pH } & \multirow[t]{2}{*}{$\begin{array}{l}\text { E.C. } \\
\text { ds } / m\end{array}$} & \multirow[t]{2}{*}{$\begin{array}{l}\text { O.M } \\
(\%)\end{array}$} & \multicolumn{3}{|c|}{$\begin{array}{c}\text { Soluble cations } \\
(\mathrm{meq} / \mathrm{L})\end{array}$} & \multicolumn{3}{|c|}{$\begin{array}{c}\text { Soluble Anions } \\
(\mathrm{meq} / \mathrm{L})\end{array}$} \\
\hline & & & & & $\mathrm{Ca}^{++}$ & $\mathbf{M g}^{++}$ & $\mathbf{K}^{+}$ & $\mathrm{HCO}_{3}$ & $\mathrm{Cl}^{-}$ & SO4 \\
\hline $0-30$ & Sandy & 7.48 & 2.01 & 0.25 & 18.60 & 10.89 & 1.00 & 6.30 & 31.26 & 8.00 \\
\hline $30-60$ & loam & 7.59 & 2.12 & 0.29 & 19.11 & 11.21 & 1.31 & 6.39 & 33.31 & 8.90 \\
\hline
\end{tabular}

Table 2. Characteristics of the cover sheet plastic

\begin{tabular}{ll}
\hline Treatments & Covering characteristics \\
\hline Soil White Plastic & Polyethylene, color white, thickness $0.120 \mathrm{~mm}$ \\
\hline Soil black plastic & Polyethylene, color black, thickness $0.120 \mathrm{~mm}$
\end{tabular}

\section{Treatments included:}

1- Black polyethylene film, BPF (From the tree trunk to the tree canopy, $0.12 \mathrm{~mm}$

thick applied from February to October each season).

2- White polyethylene film, WPF (From the tree trunk to the tree canopy, $0.12 \mathrm{~mm}$

thick applied from February to October each season).

3- Mulching with Alfalfa straw, MAS.

4- Mulching with Rice straw, MRS.

5- Compost of organic matter, COM (15m3/Fed.) applied once at December.

6- Check - plots, CP (Control).

For practical reasons, mulch plots were $1.5 \mathrm{~m}$. The straw was applied each September, using one bales of alfalfa and rice straw per plot $\left(15 \mathrm{~m}^{2}\right)$; while the compost beginning of the trial in 2009 and 2010. Each mulch was approximately $10 \mathrm{~cm}$ deep. Apple yield and trunk diameter $30 \mathrm{~cm}$ above the ground were recorded annually. Soil temperatures and soil moisture contents were monitored every month through the growing season (from late December to late May and then average of minimum and maximum were calculated).

Soil temperature was measured in the center of planted row at a depth of $10 \mathrm{~cm}$ using thermisters (model 107B, Campbell Scientific, Edmonton, AB) attached to results loggers. Soil moisture content was determined on dry weight basis $(\theta \mathrm{w})$ as the following equation

$$
(\theta \mathrm{w}) \%=\frac{\text { wet soil weight }- \text { dry soil weight }}{\text { dry soil weight }} \times 100
$$

Leaf samples were collected for nutrient analyses in May and fruit samples were taken for nutrient analyses at harvest time. organic fertilization was applied once only at the 
Leaf area was examined by portable area meter LI .COR model LI-3000 A. Initial and final shoot length was determined. Also, mean number of leaves per shoot was noticed. For determining N, P, K, Fe, Zn and Mn in the fruits and leaves, at harvest time, samples of fruits were washed with tap water and rinsed with distilled water, the fruits were separated and cut into small pieces using a clean knife and each part was mixed well. Also, 30 leaves were collected from each tree from the third leaf on shoots. Leaf samples were washed with tap water, then with distilled water and oven dried at $70 \mathrm{C}^{\circ}$ for 72 hours to a constant weight (fruit and leaf samples). The dried samples of fruits and leaves were ground and digested with sulphoric acid and hydrogen peroxide according to (Evenhuis.and Dewaard, 1980). Suitable aliquots were taken for the determination of mineral elements in leaf and fruit samples. Nitrogen and phosphorus were determined calorimetrically according to Evenhius (1976) and Murphy and Riley (1962), respectively. Potassium was determined by Flame photometer, while $\mathrm{Fe}, \mathrm{Zn}$ and $\mathrm{Mn}$ by Perkin Elmer atomic absorption Spectrophotometer. The concentrations of $\mathrm{N}, \mathrm{P}$ and $\mathrm{K}$ were expressed as percent, while those of $\mathrm{Fe}, \mathrm{Zn}$ and $\mathrm{Mn}$ were expressed as parts per million, on dry weight basis.

The mature fruits of each tree were harvested and weighed at late of June in both seasons for physical and chemical analysis. Samples of 10 fruits were taken from each tree for physical and chemical analysis. Yield, weight, diameter and length of fruits were recorded. Fruit firmness was determined according to Magness and Taylor (1925) pressure tester using a 5/16 plunger, two readings were taken on the flesh of each fruit after peeling. Fruit color was visually ranked on a scale from 1 to 5 , with $1=20 \%$ red progressive, $2=40 \%, 3=60 \%$, $4=80 \%$ and $5=100 \%$ red color. Also, anthocyanin content was determined at the stage of coloration (mg/100g fresh weight) according to Rabino et al. (1977). From these ten fruits, two fruits were used for measuring total soluble solids (TSS) using hand refractometer, acidity and starch content using A.O.A.C. (1980). Total sugars content was determined according to the procedures outlined by Malik and Singh (1980). The starch content was determined in $0.1 \mathrm{gm}$ of the residue by hydrolysis with concentrated $\mathrm{HCl}$ for 3 hours under reflux condenser (A.O.A.C., 1980). The total reducing power was determined according to Malik and Singh (1980) and the factor 0.9 was used to calculate the starch (Woodman, 1941). The obtained results throughout the two studied growing seasons were statistically analyzed using the analysis of variance (Steel and Torrie, 1980).

\section{RESULTS AND DISCUSSION}

Results in Tables (3 and 4) show the average soil temperature and moisture of apple orchard under study as affected by different mulch coverings and organic fertilization during 2009 and 2010 seasons.

Soil temperature: Results concerning the effects of different mulch coverings on mean of soil temperature in both studied seasons indicated that black polyethylene film (BPF) increased mean of soil temperatures in the first season by $2.60^{\circ} \mathrm{C}$ and $2.01^{\circ} \mathrm{C}$ in the second season, as compared with check plot treatment (CP),followed by white polyethylene film (WPF) which increased mean of soil temperatures in the first season on average by $0.96^{\circ} \mathrm{C}$ and $0.64^{\circ} \mathrm{C}$ in the second season as compared with check plot treatment $(\mathrm{CP})$. Generally, all plastic mulch covering treatments and applied compost of organic matter (COM) showed an increment in mean of soil temperatures in both seasons as compared with control treatment (Table 3). No significant differences were noticed between mulching alfalfa straw (MAS) and mulching rice straw (MRS) on one hand, and between (BPF) and (WPF), on the other. Truax and Gagnon (1993) improved soil structure and water infiltration of apple orchard by cover crops as a mulching. Moreover, Nathan et al. (2002) found in apple orchards that cover crops as mulching reduced surface soil temperature and water evaporation, improved weed control, and increased soil productivity. All treatments significantly increased the mean of soil temperatures comparing with check plot, while no differences were reported between plastic mulch coverings treatments and mulching with cover straw treatments in both seasons. These results also seemed to be in line with those obtained by Bowen et al. (2004). They showed that the polyethylene mulch increased soil temperatures by $2 \mathrm{C}^{\circ}$. Also, Mika et al. (2007) found that in 'Pinova' apple trees irradiation within a canopy was reduced by leaf shading to $26 \%$ at $0.5 \mathrm{~m}, 31 \%$ at $1.0 \mathrm{~m}, 42 \%$ at $1.5 \mathrm{~m}$ and $48 \%$ at $2.0 \mathrm{~m}$ above the ground as compared to solar irradiation above the tree. Moreover, reflective mulch increased reflected light intensity 8 times at $0.5 \mathrm{~m}, 4$ times at $1.0 \mathrm{~m}, 2$ times at $1.5 \mathrm{~m}$ and by $10 \%$ at $2.0 \mathrm{~m}$ when compared to bare soil. Moreover, Fawzia (2008) on pear noticed that, mulching trees around the trunk with black plastic tended to increase soil temperature more than white plastic.

Soil moisture: As for effects of different mulch coverings during 2009 and 2010 seasons on mean soil moisture results illustrated in Table (4) revealed that, all plastic mulch films, cover crop straws and compost of organic matter treatments caused an increase in the mean 
of maximum and minimum soil moistures in both seasons of the study. It was noticed that (BPF) treatment

Table 3. Effects of different mulch coverings on mean of soil temperature ${ }^{\circ}$ during 2009 and 2010 seasons

\begin{tabular}{lcccccc}
\hline \multirow{2}{*}{ Treatments } & \multicolumn{3}{c}{$\mathbf{2 0 0 9}$} & \multicolumn{2}{c}{ 2010 } \\
\cline { 2 - 7 } & Max. & Min. & Mean & Max. & Min. & Mean \\
\hline BPF & 24.95 & 16.13 & $20.90 \mathrm{a}$ & 24.34 & 16.46 & $20.50 \mathrm{a}$ \\
\hline WPF & 23.02 & 15.46 & $19.24 \mathrm{a}$ & 23.12 & 15.82 & $19.47 \mathrm{a}$ \\
\hline MAS & 22.98 & 15.32 & $19.15 \mathrm{~b}$ & 23.11 & 15.74 & $19.43 \mathrm{~b}$ \\
\hline MRS & 22.54 & 14.95 & $18.79 \mathrm{~b}$ & 22.98 & 15.65 & $19.32 \mathrm{~b}$ \\
\hline COM & 21.98 & 14.65 & $18.30 \mathrm{c}$ & 22.01 & 14.98 & $18.49 \mathrm{c}$ \\
\hline CP $($ Control $)$ & 20.16 & 14.43 & $17.30 \mathrm{~d}$ & 20.89 & 14.77 & $17.83 \mathrm{~d}$ \\
\hline
\end{tabular}

Table 4. Effects of different mulch coverings on mean of soil Moisture \% during 2009 and 2010 seasons

\begin{tabular}{lcccccc}
\hline \multirow{2}{*}{ Treatments } & \multicolumn{3}{c}{$\mathbf{2 0 0 9}$} & \multicolumn{3}{c}{$\mathbf{2 0 1 0}$} \\
\cline { 2 - 7 } BPF & Max. & Min. & Mean & Max. & Min. & Mean \\
\hline WPF & 74.35 & 54.35 & $64.35 \mathrm{a}$ & 78.32 & 53.24 & $65.78 \mathrm{a}$ \\
\hline MAS & 76.35 & 55.21 & $65.48 \mathrm{a}$ & 76.34 & 55.24 & $65.79 \mathrm{a}$ \\
\hline MRS & 72.32 & 52.69 & $62.51 \mathrm{~b}$ & 74.25 & 52.34 & $63.29 \mathrm{~b}$ \\
\hline COM & 69.54 & 50.32 & $59.93 \mathrm{~b}$ & 71.34 & 51.24 & $61.29 \mathrm{~b}$ \\
\hline CP $($ Control) & 66.32 & 47.54 & $56.93 \mathrm{c}$ & 69.35 & 49.21 & $59.28 \mathrm{c}$ \\
\hline
\end{tabular}

gave the highest values of soil moisture followed by (WPF) treatments, while the (COM) and (CP) treatments gave the lowest values in both seasons. All treatments significantly increased the mean of soil moistures comparing with check plot, while no differences were reported between plastic mulch coverings treatments and mulching with cover straw treatments in both seasons. Truax and Gagnon (1993); Marsh et al. (1996), Nathan et al. (2002) and Lindhard et al. (2007) on apple found that mulching with cover crops improved soil structure and water infiltration, also showed that apple trees planted in soil covered by black plastic had high soil moisture content. Several recent trials in humid regions have identified beneficial effects of mulching on apple tree performance, soil moisture content and biological activity in orchard soils (Neilsen et al., 2008).

As for the effects of different mulch coverings and organic fertilization on some morphological parameters of "Anna" apple trees during 2009 and 2010 seasons, results are presented in Table (5).

Shoot length: Regarding the percentages of increment in shoot length as affected by different treatments, results revealed that, mulching with plastic films around the trees gave the highest increment in shoot length, followed by mulching with alfalfa or rice coverings soil treatments as compared to check plot treatment, while the compost organic matter treatment gave the lowest value in both experimental seasons. All treatments significantly increased shoot length comparing with check plot, while no differences were reported between plastic mulch coverings treatments and mulching with cover straw treatments in both seasons. No significant difference was found between two mulching with plastic films on one hand, and between mulching with two covering crops on the other. The increment of shoot length comparing to check plot may be due to stimulated root growth caused by increased soil temperature and moisture given under mulching coverings with plastic films leading to early top growth (Jones et al., 1978). Furthermore, Lindhard et al. (2007) revealed that, mulch application most consistently affected tree growth, as indicated in a long term field trial where cumulative yield after 5 crop years was increased by surface application of shredded paper, alfalfa and bio-solid mulches. Also, on young apple trees planted in soil covered by black plastic, Mika et al. (2007) noticed that the trees had the most vigorous growth and the trees in permanent grass sod had the lowest growth.

Leaves number: As for number of leaves/shoot results tabulated in Table (5) demonstrated that, BPF, WPF, MAS, MRS, COM and CP treatments gave 33.00, 34.00, $31.00,29.00,25.00$ and 23.00 leaves in the first season, while they gave 32.00, 33.00, 29.00, 27.00, 26.00 and 25.00 leaves in the second season, respectively. It was noticed that, mulching trees with white polyethylene films (WPF) increased significantly the No. of leaves/shoot as compared with control treatment in both seasons. Mulching with cover crops either alfalfa or rice reduced the No. of leaves/shoot as compared with mulching with polyethylene films either black or white in both experimental seasons. At the same time, 
compost organic matter treatment caused a reduction in the No. of

Table 5. Effects of different mulch coverings on some morphological properties of "Anna" trees during 2009 and 2010 seasons

\begin{tabular}{ccccccc}
\hline & \multicolumn{3}{c}{$\mathbf{2 0 0 9}$} & \multicolumn{3}{c}{$\mathbf{2 0 1 0}$} \\
\cline { 2 - 7 } Treatments & $\begin{array}{c}\text { \% } \\
\text { increment } \\
\text { in shoot } \\
\text { length }\end{array}$ & No. & Leaf area & $\begin{array}{c}\text { \% } \\
\text { increment } \\
\text { leaves/shoot }\end{array}$ & $\begin{array}{c}\text { No. } \\
\text { leaves/ } \\
\text { shoot }\end{array}$ & Leaf area \\
(cm2)
\end{tabular}

leaves/shoot comparing to mulching with polyethylene films or covering crops treatments in two seasons. All treatments increased significantly number of leaves/shoot comparing with check plot, while no differences were reported between plastic mulch coverings treatments and mulching with cover straw treatments in both seasons. No significant difference was found between two mulching with plastic films on one hand, and between mulching with two covering crops on the other. The same trend was found by Davison (1982) who reported that increasing in the vegetative growth of apple trees was achieved when mulched the trees with black polyethylene around $30 \%$ compared with $10 \%$ for straw mulching. Also, Neilsen et al. (2008) found that all treatments of mulching increased the performance of tree growth.

Leaf area: Regarding the leaf area as affected by different treatments, results revealed that, mulching the trees with plastic films around the trees gave the highest leaf area, followed by mulching with alfalfa or rice coverings soil treatments as compared with check plot treatment, while the compost organic matter treatment gave the lowest value in both experimental seasons. No significant difference was found between two mulching with plastic films on one hand, and between mulching with two covering crops on the other. The increment of leaf area comparing to check plot may be due to stimulated root growth caused by increased soil temperature and moisture given under mulching coverings with plastic films leading to early top growth. Lindhard et al. (2007) revealed that, mulch application most consistently affected tree growth, as indicated in a long term field trial where cumulative yield after 5 crop years was increased by surface application of shredded paper, alfalfa and biosolid mulches. Also, on young apple trees planted in soil covered by black plastic,

Mika et al. (2007) noticed that the trees had the most vigorous growth and the trees in permanent grass sod had the lowest growth. Also, they found that, the biggest leaf area was found at the horizontal layer between 1.5 and $2.0 \mathrm{~m}$. Leaf area index assessed per canopy cast to the ground was 0.45 . Irradiation within 'Jonagored' apple canopy, fruit and leaf distribution was similar to these in 'Pinova'.

Fruit physical properties: As for the effects of different treatments on some physical properties of fruits, results illustrated in Table (6) showed that, all mulching treatments with plastic films, covering crops, as well as, compost organic matter caused an increasing in mean fruit weight $(\mathrm{g})$, Wt. fruits/tree $(\mathrm{Kg})$, fruit length (cm), fruit diameter ( $\mathrm{cm}$ )and fruit firmness (Ib/inch2) as compared with check plot treatment in both seasons. It was noticed that, mulching trees with white polyethylene films (WPF)significantly increased the fruit physical properties as compared with control treatment in both seasons. Mulching with cover crops either alfalfa or rice reduced the fruit physical properties as compared with mulching with polyethylene films either black or white in both experimental seasons. At the same time, compost organic matter treatment caused a reduction in the fruit physical properties comparing mulching with polyethylene films or covering crops treatments in two seasons. The same results were confirmed by El-Seginy (2000) on Le-Conte pear who found that mulching treatments increased fruit physical propertied as compared with control. Also, Reganold (2006) found that the organic apples were either firmer fruits or always as firm as the conventional and integrated apples, while Mika et al. (2007) found that, no significant influence of mulching on mean fruit weight and fruit firmness. They all suggested that, the higher moisture and temperature and better nutrient 
availability by reduction of leaching offered by in fruit physical properties.

mulching may have been the reasons for the increasing

Table 6. Effects of different mulch coverings on yield and some physical fruit properties of "Anna" trees during 2009 and 2010 seasons

\begin{tabular}{|c|c|c|c|c|c|c|c|c|c|c|}
\hline \multirow{2}{*}{ 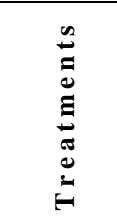 } & \multicolumn{5}{|c|}{2009} & \multicolumn{5}{|c|}{2010} \\
\hline & $\begin{array}{l}\text { Fruit } \\
\text { weight } \\
\text { (g) }\end{array}$ & $\begin{array}{c}\text { Wt. fruits/ } \\
\text { tree } \\
(\mathrm{Kg})\end{array}$ & $\begin{array}{c}\text { Fruit } \\
\text { length } \\
(\mathrm{cm})\end{array}$ & $\begin{array}{c}\text { Fruit } \\
\text { diamet } \\
\text { er }(\mathbf{c m})\end{array}$ & $\begin{array}{c}\text { Fruit } \\
\text { firmness } \\
\left(\mathbf{I b} / \text { inch }^{2}\right)\end{array}$ & $\begin{array}{l}\text { Fruit } \\
\text { weight } \\
\text { (g) }\end{array}$ & $\begin{array}{c}\text { Wt. fruits/ } \\
\text { tree } \\
(\mathrm{Kg})\end{array}$ & $\begin{array}{l}\text { Fruit } \\
\text { length } \\
(\mathrm{cm})\end{array}$ & $\begin{array}{c}\text { Fruit } \\
\text { diameter } \\
(\mathrm{cm})\end{array}$ & $\begin{array}{c}\text { Fruit } \\
\text { firmness } \\
\left(\text { Ib/inch }{ }^{2}\right)\end{array}$ \\
\hline BPF & $131.32 b$ & $43.25 b$ & $6.99 \mathrm{~b}$ & $6.89 \mathrm{~b}$ & $16.35 b$ & $131.25 b$ & $45.25 b$ & $7.12 b$ & $7.12 \mathrm{~b}$ & $17.98 \mathrm{a}$ \\
\hline WPF & $135.02 \mathrm{a}$ & $45.23 \mathrm{a}$ & $7.12 \mathrm{a}$ & $7.02 \mathrm{a}$ & $17.78 \mathrm{a}$ & $136.21 \mathrm{a}$ & $47.54 \mathrm{a}$ & $7.25 \mathrm{a}$ & $7.22 \mathrm{a}$ & $17.99 \mathrm{a}$ \\
\hline MAS & $129.12 \mathrm{c}$ & $41.87 \mathrm{c}$ & $6.67 \mathrm{c}$ & $6.70 \mathrm{c}$ & $15.99 \mathrm{c}$ & $129.52 c$ & $44.89 \mathrm{c}$ & $7.00 \mathrm{c}$ & $7.01 \mathrm{c}$ & $17.36 \mathrm{~b}$ \\
\hline MRS & $126.23 \mathrm{c}$ & $40.27 \mathrm{c}$ & $6.54 \mathrm{c}$ & $6.66 \mathrm{c}$ & $15.89 \mathrm{c}$ & $128.87 \mathrm{c}$ & $39.35 \mathrm{~d}$ & $6.96 c$ & $6.99 \mathrm{c}$ & $16.38 \mathrm{bc}$ \\
\hline COM & $123.25 \mathrm{~d}$ & $38.89 \mathrm{~d}$ & $6.45 c$ & $6.56 \mathrm{~d}$ & $15.64 d$ & $125.56 \mathrm{~d}$ & $39.24 d$ & $6.54 \mathrm{~d}$ & $6.44 d$ & $16.92 \mathrm{bc}$ \\
\hline $\begin{array}{c}\mathbf{C P} \\
(\text { Contro) }\end{array}$ & $115.36 \mathrm{e}$ & $34.26 \mathrm{e}$ & $6.15 d$ & $6.21 \mathrm{e}$ & $15.27 \mathrm{e}$ & $118.21 \mathrm{e}$ & $37.24 \mathrm{e}$ & $6.24 \mathrm{e}$ & $6.35 \mathrm{e}$ & $16.87 \mathrm{c}$ \\
\hline
\end{tabular}

Fruit chemical characteristics: Effects of different mulch coverings on some chemical fruit properties of "Anna" trees during 2009 and 2010 seasons are presented in Table (7). Fruit color percentages had greater light intensity at all polyethylene films applications than light reflected from the other covering crops, compost organic matter and untreated trees. In both experimental seasons, results showed that, the spectral distribution of the reflected light from the BPF and WPF treatments was more significant than other remained treatments. Also, results mentioned that light reflected from the films either mulching with polyethylene or covering crops was different in quantity. It was noticed that, the increment in the concentrations of fruit color percentages reduced the light intensity in the mulching with cover crops than in mulching with polyethylene films. Also, significant differences were found between polyethylene films treatments and all remainder treatments. The same trend was found for anthocyanin contents in fruits in both seasons. This observation is consistent with previous findings by Andrias and Crisosto (1996) and Tarara (2000) which reported that, the quality of reflected light from the film was not different from direct sunlight, but it was reduced in intensity, also reflection of solar radiation by film modified the orchard microclimate. Moreover, Mika et al. (2007) found that reflective mulching improved significantly red blush on 'Jonagored' apples, and in the next season there was no effect because on mulched and control trees all apples had $100 \%$ of red skin.

As for the effects of different mulch coverings on some chemical fruit properties of "Anna" trees during 2009 and 2010 seasons, results in Table (7) concerning the TSS $\%$ and acidity $\%$ results showed that mulching treatments either with polyethylene or covering crops decreased the two parameters comparing with control treatment in both seasons, while the reverse was true for starch $\%$ and total sugar \%. Statistical analysis revealed that, mulching with white plastic films around the trunk of trees significantly increased all chemical fruit properties of "Anna" trees during 2009 and 2010 seasons comparing with control. These results disagree with those reported by El-Seginy (2000), while they agree with those obtained by Lindhard et al. (2007).

As for the effects of different treatments on leaf and fruit mineral contents, results in Tables (8 and 9) revealed that, all applied treatments, significantly increased leaf and fruit $\mathrm{N}, \mathrm{P}, \mathrm{K}, \mathrm{Fe}, \mathrm{Zn}$ and $\mathrm{Mn}$ as compared with control treatment in both seasons. White plastic film (WPF) resulted high values of different nutrients followed by (BPF), while the control treatment was the least in this regard in both seasons. Statistical analysis showed that mulching with plastic films white or black increased significantly the contents of leaves and fruits from different minerals in the two seasons as compared with contol. The same findings were recorded by Frimanslund (1984) and Fawzia (2008) on pear, Neilsen et al. (1986), Nathan et al. (2002) and Mika et al. (2007) on apple. For all species, the nitrogen levels were within or above the normal range. The highest nitrogen levels were found in the trees planted with a red clover. This is because red clover is a legume and can fix nitrogen into the soil. Compost increased leaf nitrogen levels by about $30 \%$ into the upper end of the recommended range for apples. Recently, Neilsen et al. (2008) reported that, little information was available concerning the effects of mulching in high-density apple orchards in irrigated regions where daily irrigation and fertigation might be expected to reduce potential nutrient and water stresses. Moreover, mulching plays an important role in development of potassium-deficiency. 


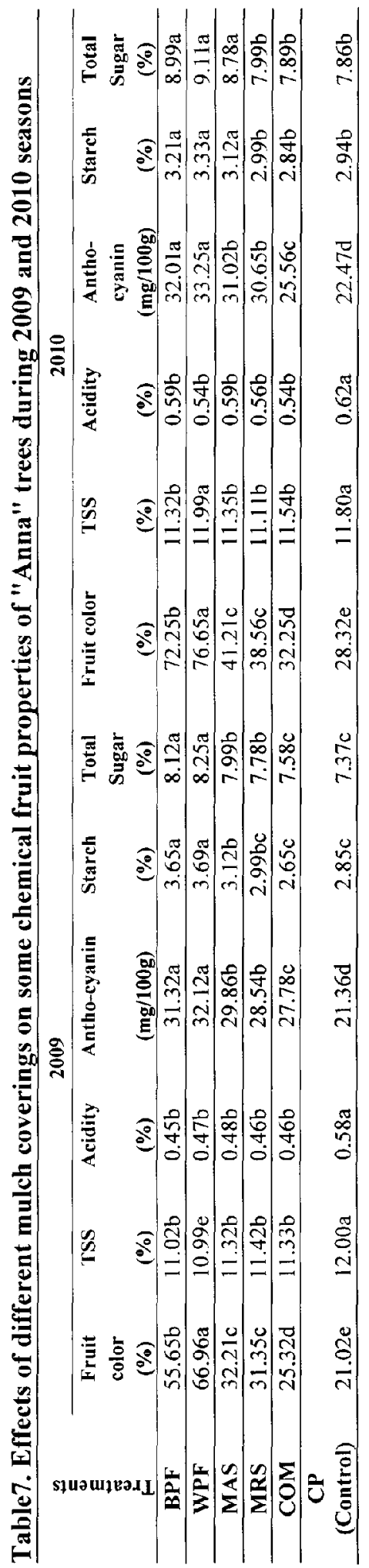


Table 8. Effects of different mulch coverings on some leaf mineral contents of "Anna" trees during 2009 and 2010 seasons

\begin{tabular}{|c|c|c|c|c|c|c|c|c|c|c|c|c|}
\hline \multirow{2}{*}{ 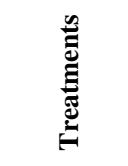 } & \multicolumn{6}{|c|}{2009} & \multicolumn{6}{|c|}{2010} \\
\hline & $\begin{array}{c}N \\
(\%)\end{array}$ & $\begin{array}{c}P \\
(\%)\end{array}$ & $\begin{array}{c}\mathbf{K} \\
(\%)\end{array}$ & $\begin{array}{c}\mathrm{Fe} \\
(\mathbf{p p m})\end{array}$ & $\begin{array}{c}\mathbf{Z n} \\
(\mathbf{p p m})\end{array}$ & $\begin{array}{c}\text { Mn } \\
(\mathbf{p p m})\end{array}$ & $\begin{array}{c}N \\
(\%)\end{array}$ & $\begin{array}{c}P \\
(\%)\end{array}$ & $\begin{array}{c}K \\
(\%)\end{array}$ & $\begin{array}{c}\mathbf{F e} \\
(\mathbf{p p m})\end{array}$ & $\begin{array}{r}\mathbf{Z n} \\
(\mathbf{p p m})\end{array}$ & $\begin{array}{r}\text { Mn } \\
(\mathbf{p p m})\end{array}$ \\
\hline BPF & $2.01 \mathrm{~b}$ & $0.32 \mathrm{a}$ & $1.06 \mathrm{a}$ & $302 \mathrm{~b}$ & $59 \mathrm{~b}$ & $46 a$ & $2.11 \mathrm{~b}$ & $0.31 \mathrm{a}$ & $1.21 \mathrm{~b}$ & $299 \mathrm{a}$ & $61 \mathrm{a}$ & $32 \mathrm{a}$ \\
\hline WPF & $2.21 \mathrm{a}$ & $0.35 \mathrm{a}$ & $1.12 \mathrm{a}$ & $301 \mathrm{~b}$ & $65 \mathrm{a}$ & $52 \mathrm{a}$ & $2.3 \mathrm{a} 1$ & $0.36 \mathrm{a}$ & $1.35 \mathrm{a}$ & $302 \mathrm{a}$ & $69 a$ & $34 \mathrm{a}$ \\
\hline MAS & $2.01 \mathrm{~b}$ & $0.33 \mathrm{a}$ & $1.09 \mathrm{a}$ & $308 \mathrm{c}$ & $62 a$ & $50 \mathrm{a}$ & $2.22 \mathrm{c}$ & $0.34 \mathrm{a}$ & $1.32 \mathrm{a}$ & $278 \mathrm{~b}$ & $62 a$ & $33 a$ \\
\hline MRS & $1.99 \mathrm{~b}$ & $0.29 \mathrm{a}$ & $1.02 \mathrm{abc}$ & $278 \mathrm{c}$ & $59 \mathrm{~b}$ & $48 \mathrm{a}$ & $2.09 \mathrm{~d}$ & $0.29 b$ & $1.21 \mathrm{~b}$ & $274 b$ & $58 \mathrm{~b}$ & $29 b$ \\
\hline COM & $1.98 \mathrm{~b}$ & $0.24 b$ & $1.00 \mathrm{bc}$ & $269 \mathrm{~d}$ & $51 \mathrm{c}$ & $32 \mathrm{~b}$ & $2.02 \mathrm{e}$ & $0.25 b$ & $1.11 \mathrm{c}$ & $269 \mathrm{c}$ & $49 b$ & $27 \mathrm{~b}$ \\
\hline $\begin{array}{c}\mathrm{CP} \\
\text { (Control) }\end{array}$ & $1.85 \mathrm{c}$ & $0.20 \mathrm{~b}$ & $0.97 \mathrm{c}$ & $265 \mathrm{~d}$ & $47 c$ & $24 c$ & $1.91 \mathrm{e}$ & $0.22 \mathrm{c}$ & $1.02 \mathrm{c}$ & $267 \mathrm{c}$ & $48 \mathrm{~b}$ & $25 \mathrm{~b}$ \\
\hline
\end{tabular}

Table 9. Effects of different mulch coverings on some fruit mineral contents of "Anna" trees during 2009 and 2010 seasons

\begin{tabular}{|c|c|c|c|c|c|c|c|c|c|c|c|c|}
\hline \multirow{2}{*}{ 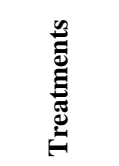 } & \multicolumn{6}{|c|}{2009} & \multicolumn{6}{|c|}{2010} \\
\hline & $\begin{array}{c}\mathbf{N} \\
(\%)\end{array}$ & $\begin{array}{c}\mathbf{P} \\
(\%)\end{array}$ & $\begin{array}{c}\mathbf{K} \\
(\%)\end{array}$ & $\begin{array}{c}\mathbf{F e} \\
(\mathbf{p p m})\end{array}$ & $\begin{array}{c}\mathbf{Z n} \\
(\mathbf{p p m})\end{array}$ & $\begin{array}{r}\text { Mn } \\
(\mathbf{p p m})\end{array}$ & $\begin{array}{c}\mathbf{N} \\
(\%)\end{array}$ & $\begin{array}{c}\mathbf{P} \\
(\%)\end{array}$ & $\begin{array}{c}\mathbf{K} \\
(\%)\end{array}$ & $\begin{array}{r}\mathbf{F e} \\
(\mathbf{p p m})\end{array}$ & $\begin{array}{c}\mathbf{Z n} \\
(\mathbf{p p m})\end{array}$ & $\begin{array}{c}\text { Mn } \\
(\mathbf{p p m})\end{array}$ \\
\hline BPF & $1.88 \mathrm{a}$ & $0.37 \mathrm{a}$ & $1.11 \mathrm{~b}$ & $72 \mathrm{a}$ & $30 \mathrm{a}$ & $48 \mathrm{a}$ & $1.98 \mathrm{a}$ & $0.41 \mathrm{a}$ & $1.19 \mathrm{a}$ & $92 \mathrm{a}$ & $31 \mathrm{a}$ & $42 \mathrm{a}$ \\
\hline WPF & $1.89 \mathrm{a}$ & $0.39 \mathrm{a}$ & $1.22 \mathrm{a}$ & $84 a$ & $35 \mathrm{a}$ & $51 \mathrm{a}$ & $1.94 \mathrm{a}$ & $0.42 \mathrm{a}$ & $1.22 \mathrm{a}$ & $96 \mathrm{a}$ & $35 \mathrm{a}$ & $45 \mathrm{a}$ \\
\hline MAS & $1.82 \mathrm{~b}$ & $0.38 \mathrm{a}$ & $1.19 \mathrm{a}$ & $78 \mathrm{~b}$ & $32 \mathrm{a}$ & $50 \mathrm{a}$ & $1.89 \mathrm{~b}$ & $0.36 \mathrm{~b}$ & $1.19 \mathrm{a}$ & $94 \mathrm{a}$ & $32 \mathrm{a}$ & $43 a$ \\
\hline MRS & $1.71 \mathrm{~b}$ & $0.36 \mathrm{a}$ & $1.02 \mathrm{~b}$ & $77 \mathrm{~b}$ & $27 \mathrm{~b}$ & $44 \mathrm{~b}$ & $1.79 \mathrm{~b}$ & $0.37 \mathrm{~b}$ & $1.15 \mathrm{a}$ & $89 \mathrm{~b}$ & $26 \mathrm{~b}$ & $39 \mathrm{~b}$ \\
\hline $\mathrm{COM}$ & $1.69 \mathrm{c}$ & $0.32 \mathrm{a}$ & $1.02 \mathrm{~b}$ & $76 \mathrm{~b}$ & $27 \mathrm{~b}$ & $40 \mathrm{c}$ & $1.62 \mathrm{c}$ & $0.35 \mathrm{~b}$ & $0.99 \mathrm{~b}$ & $87 \mathrm{~b}$ & $27 \mathrm{~b}$ & $36 \mathrm{~b}$ \\
\hline $\begin{array}{c}\text { CP } \\
\text { (Control) } \\
\end{array}$ & $1.42 \mathrm{~d}$ & $0.29 \mathrm{~b}$ & $0.95 \mathrm{c}$ & $76 \mathrm{~b}$ & $18 \mathrm{c}$ & $38 \mathrm{c}$ & $1.47 \mathrm{~d}$ & $0.32 \mathrm{c}$ & $0.89 \mathrm{c}$ & $81 \mathrm{c}$ & $22 \mathrm{c}$ & $34 \mathrm{~b}$ \\
\hline
\end{tabular}

\section{CONCLUSION}

It can be concluded from the above mentioned results that, plastic mulch coverings treatments and applied compost of organic matter (COM) caused an increment in mean of soil temperatures and moisture content as compared with control treatment. The increment of morphological parameters and fruit physical and chemical properties by using the plastic mulching especially white plastic films comparing to check plot may be due to stimulated root growth caused by increased soil temperature and moisture given under mulching coverings with plastic films leading to early top growth.

\section{REFERENCES}

Andrias, H. and C. H. Crisosto (1996). Reflective materials enhance 'Fuji' apple 13-16color. Calif. Agr. 50(5): 2730.

A.O.A.C. (Association of official Agricultural Chemists) (1980). Official methods for analysis, $13^{\text {th }}$ ed. Association of official analytical chemists, Washington, D. C., USA.
Balesdent, J., C. Chenu and M. Balabane (2000). Relationship of soil organic matter dynamics to physical protection and tillage. Soil and Tillage Res. 53:215-230.

Bowen, P. A., Bogdanoff, C. P. and B. Estergaard (2004). Impacts of using polyethylene sleeves and wavelengthselective mulch in vineyards. I. Effects on air and soil temperatures and degree day accumulation. Can. J. Plant Sci., 4:545-553.

Cambardella, C. A., and E.T. Elliott (1993). Carbon and nitrogen distribution in aggregates from cultivated and native grasslands soils. Soil Sci. Soc. Amer. J. 56:777783 .

Davison, J. G. (1982). Black plastic benefit young fruit trees and Bushes. Blasticulture, 193: 35-40.

El-Seginy, Amal M. (2000). The effect of mulching and clean cultivation on Le-conte pear trees grown in new reclaimed area. J. Agric. Sci. Mansoura Univ., 25(12): 8053-8061.

Evenhuis, B. (1976). Simplified methods for foliar analysis, Parts I -VII. Internal Report Dept., Agric. Res., Royal Tropical Inst., Amsterdam, PP. 1-13.

Evenhuis, B. and B. W. Dewaard (1980). Principles and practices in plant analysis. FAO Soils Bull., 38(1):152163. 
Fawzia, M. Eissa (2008). Effect of the use of coloured plastic mulching on growth, yield components and fruit quality of Le-Conte pear trees. Minufia J. Agric Res. 33(5): 1157-1177.

Frimanslund, E. (1984). Young pear trees in soil with black plastic mulching compared to grass. Forsking Landbruk, 35: 35-40.

Granatstein, D. (2002). Tree fruit production with organic farming methods. Organic Fruit Production, 15: 1-12.

Hamm U., F. Gronefeld, and D. Halpin (2002). Analysis of the European market for organic food: Organic marketing initiatives and rural development. 1:15-21.

Hanna, R., F. G. Zalom, and C. L. Elmore (1995). Integrating cover crops into grapevine pest and nutrition management: The transition phase. Sustainable Technical Reviews. 7 (3): 11-14.

Jones, T. L.; L. Sandwell and C. J. Talent (1978). The effect of soil temperatures when associated with low air temperature on the cropping of early tomatoes. Acta Hort., 76: 167-171.

Lindhard, P., R. Hanna and K. Birka (2007). Cover crop and mulching effects on yield and fruit quality in unsprayed organic apple production. Biol. Agric. \& Hort., 15:12-18.

Magness, J. R. and C. F. Taylor (1925). An improved type of pressure tester for the determination of fruit maturity. U. S. Dept. Agric. Circ. PP: 350-358.

Malik, C. P. and M. B. Singh (1980). Plant enzymology and histoenzymology. A Text Manual. Kalyani Publishers, New Delhi.

Marsh, K. B., M. J. Daly, and T. P. McCarthy (1996). The effect of understory management on soil fertility, tree nutrition, fruit production and apple fruit quality. Biol. Agric. and Hort., 13:161-173.

Mika, A. Treder, W. Buler, Z. Rutkowski, K. B. Michalska (2007). Effects of orchard mulching with reflective mulch on apple tree canopy irradiation and fruit quality. J. Fruit \& Orn. Plant Res., 15: 41-54.

Murphy, J. and J. P. Riley (1962). A modified single solution method for determination of phosphorus in natural water. Anal. Acta., 27: 31-36.
Nathan, L., M. Hartwig and H. U. Ammon (2002). Cover crops and living mulches. Weed Sci. Soc. Amer., 85:4556.

National Research Council (1989). Alternative Agriculture. National Academy, Washington, D.C . PP: 423.

Neilsen, G. H., E. J. Hogue, T. Forge, and D. Neilsen (2008). Mulches and biosolids affect vigor, yield and leaf nutrition of fertigated high density apple. Agric. and Agric-Food Canada, Pacific Agric-Food Res. Centre, Summerland, B.C.

Rabino, L., L. Alberto and M. K. Monrad (1977). Photocontrol of anthocyanin synthesis. J. Plant Physiol., 59: 569-573.

Reganold, J. (2006) Sustainability of organic, conventional, and integrated apple orchards. Plant Management Network. Dep. of Crop \& Soil Sci., Wash. State Univ., Pullman, WA 99164.

Reganold, J. P., Elliott, L.F., Unger, Y. L., (1987). Long-term effects of organic and conventional farming on soil erosion. Nature, 330: 370-372.

Reganold, J. P., Jerry D. Glover, Preston K. Andrews, and Herbert R. Hinman (2001). Sustainability of three apple production systems. Nature, 410: 152-164.

Sainju, U. M, and B. P. Singh (1997). Winter cover crops for sustainable-agricultural systems: Influence on soil properties, water quality, and crop yields. HortScience 32:21-28.

Steel, R. G. D. and T. H. Torrie (1980). Principles and procedures of statistics. N.Y 2nd ed. McGraw Hill, N. Y., U. S. A., PP: 321.

Swezey, S. L., Werner, M. R., Buchanan, M., Allison, J. (1998). Comparison of conventional and organic apple production systems during three years of conversion to organic management in coastal Calif. Amer. J. Alter. Agric., 13, 162-180 .

Tarara, J. M. (2000). Microclimate modification with plastic mulches. HortScience 35:169-180.

Truax, B. and D. Gagnon (1993). Effects of straw and black plastic mulching on the initial growth and nutrition of butternut, white ash and bur oak. Forest Ecol. and Manag., 57 (1-4): 17-27.

Woodman, A. G. (1941). Food analysis. McGraw-Hill Book Company, Ince. New York. 


\section{الملنخص العربي}

\section{تأثير التسميد العضوي، محاصيل التغطية والتغطية بالبالاستيك على درجة حرارة ورطوبة التربة، النمو الخضرى، الخصول وجودة الثمار على أشجار الثفاح "آنا"}

$$
\text { محمود أحمد علي، بنجوى أبو المجد عبد البحيد، عفاف محمد علي يوسف }
$$

بقش البرسيم أو الأرز بينما معاملة التسميد العضوي أعطت أقــل

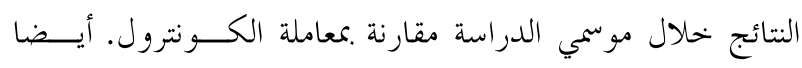

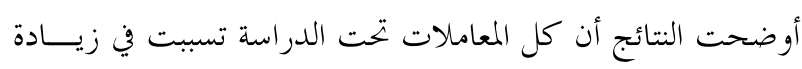
كل من متوسط وزن الثمرة، وزن الثمار/شجرة، طول وقطر الثمرة وصلابة الثمار خلال موسيمي الدراسة مقارنة مععاملـــة الكــــنترول.

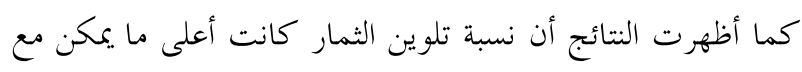
التغطية بالبلاستيك مقارنة بباقي المعاملات و كذلك الكونترول وقد تحققت نفس النتائج بالنسبة لمحتوى الثمار من الأنثوسيانين خـــلال

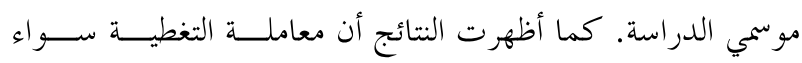
بالبلاستيك أو القش خفضت من قيم الحموضة والمواد الصلبة الذائبة بينما العكس صحيح بالنسبة لمتوى النشا والسكريات الكلية خحلال موسمي الدراسة مقارنة مععاملة الكونترول. كما أوضحت النتائج أن

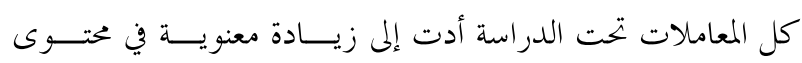

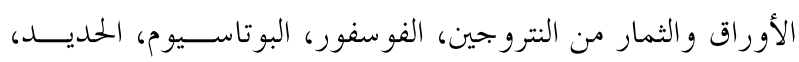
الزنك والمنجنيز خلال موسمي الدراسة مقارنة بمعاملة الكونترول.
تم معاملة أشجار تفاح صنف "آنا" مطعوم على أصل مـــــنج

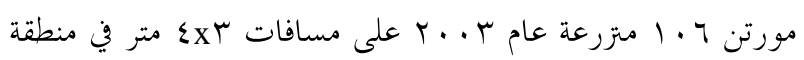

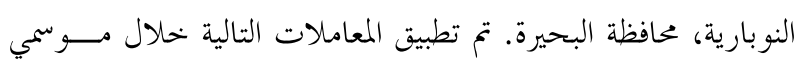

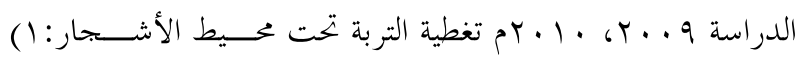

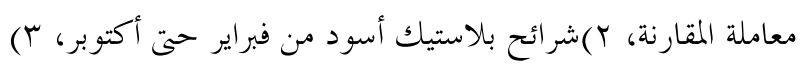

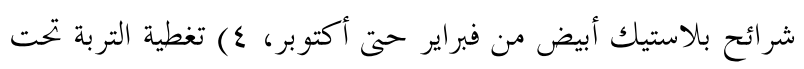
محيط الأشجار بقش البرسيم، 0) تغطية التربة تحت محيط الأشجار بقش الأرز،7) ما مب سماد عضوي للفدان في ديسمبر مرة واحدة.

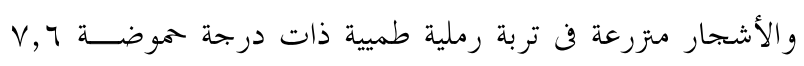
و نظام الري بالتنقيط. أشارت النتائج أن معاملات التغطيـــة بالبلاســتيك ومعاملـــة

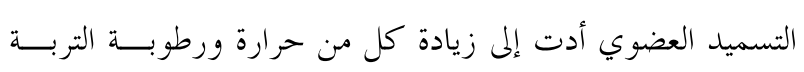

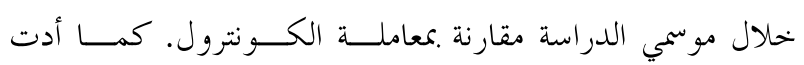
معاملات التغطية بالباستيك إلى زيادة في طول النموات الخضرية،

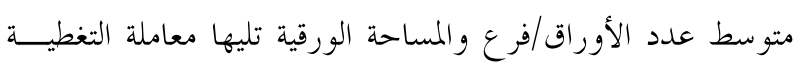

